\title{
PROBLEMATIKA DAN KEPUASAN SISWA DALAM MENGHADAPI PEMBELAJARAN JARAK JAUH DI SEKOLAH MENENGAH
}

\author{
M. Dahlan $\mathbf{R}^{1}$, Salma Zahratusholihah ${ }^{2}$, Kholil Nawawi ${ }^{3}$ \\ Pendidikan Agama Islam, Universitas Ibn Khaldun Bogor ${ }^{1,2,3}$ \\ Email: salmazahratusholihah@gmail.com
}

\begin{abstract}
Abstrak
Pandemi Covid-19 telah mengakibatkan perubahan dalam bidang pendidikan, sehingga menimbulkan berbagai problematika dalam pembelajaran. Sebab adanya problematika tersebut maka muncul respon tersendiri bagi siswa sebagai gambaran kepuasannya terhadap pembelajaran yang dilakukan. Respon tersebut akan menentukan sikap siswa dalam pembelajaran, sehingga mempengaruhi pada ketercapaian tujuan pembelajaran. Maka tujuan penelitian ini adalah untuk mengetahui problematika dan kepuasan siswa dalam pembelajaran jarak jauh. Penelitian dilaksanakan menggunakan metode kualitatif dengan pendekatan field research. Data diambil dengan menggunakan metode observasi, angket yang diberikan kepada siswa secara online melalui google form, dan dokumentasi. Kemudian data dianalisis melalui kegiatan reduksi, penyajian data, dan kesimpulan. Hasil penelitian menunjukkan bahwa problematika pembelajaran jarak jauh yang terjadi di SMP Negeri 1 Pamijahan memperoleh persentase sebesar 58\%, sehingga tergolong dalam kategori cukup baik, yang berarti problem yang terjadi tidak begitu serius. Adapun kepuasan siswa dalam pembelajaran jarak jauh memperoleh persentase sebesar 67\%, sehingga tergolong dalam kategori cukup puas. Aspek yang perlu dilakukan perbaikan karena masuk dalam kategori tidak baik dalam problematika yaitu aspek pemahaman materi dan interaksi, serta kurang puas pada aspek materi dan metode pembelajaran
\end{abstract}

Kata Kunci : Pembelajaran Jarak Jauh, Problematika, Kepuasan.

\begin{abstract}
The Covid-19 pandemic has resulted changes in education, causing various problems in learning. Because of these problems, there are certain responses from students as a picture of their satisfaction with the learning carried out. This response will determine students' attitudes in learning, thus affecting the achievement of learning objectives. Therefore, the purpose of this study is to determine the problems and student satisfaction in distance learning. The research was conducted using qualitative methods with a field research approach. Data were collected using the observation method, questionnaires given to students via google form, and documentation. Then the data were analyzed through reduction activities, data presentation, and conclusions. The results showed that the problem of distance learning that occurred in SMP Negeri 1 Pamijahan obtained a percentage of $58 \%$, so it was classified as quite good, which inferred that the problem that occurred was not quite serious. The student satisfaction in distance learning obtained a percentage of $67 \%$, thus it was classified as quite satisfactory. The aspects that need improvement because they resulted in bad category were aspects of understanding material and interaction, and less satisfied with aspects of material and learning methods.
\end{abstract}

Key Words : Distance Learning, Problematics, Satisfaction.

\section{PENDAHULUAN}

Covid-19 merupakan virus yang telah menginfeksi jutaan orang dan menyebabkan kasus kematian yang tinggi, termasuk Indonesia. Sehingga pada tanggal 11 Maret 2020 Badan Kesehatan Dunia (WHO) menetapkan wabah ini sebagai pandemi global [1]. Keadaan terjangkitnya wabah membuat pemerintah Indonesia merespon khususnya dalam bidang pendidikan melalui Kemendikbud dengan diterbitkannya SK No 4 Tahun 2020 demi melindungi siswa dari terjangkitnya wabah. Dalam SK tersebut dijelaskan di antaranya bahwa proses belajar dilakukan dari rumah atau dengan kata lain menggunakan sistem pembelajaran jarak jauh atau daring (dalam jaringan) dengan 
memberikan pengalaman belajar yang bermakna bagi siswa serta dilaksanakan sesuai dengan minat siswa dan fasilitas belajar yang tersedia di rumah masingmasing [2]. Dengan demikian, terjadilah perubahan bentuk pembelajaran yang dikenal dengan pembelajaran jarak jauh. Pembelajaran jarak jauh merupakan pembelajaran yang dilaksanakan dengan tidak menghubungkan antar siswa dan guru pada satu lokasi, mereka harus melakukan pembelajaran dari tempat yang terpisahpisah [3].

Pembelajaran merupakan sebuah sistem, maka komponen yang berada di dalamnya harus dapat berfungsi dengan baik dan saling berkaitan. Jika terjadi perubahan pada salah satunya, maka akan terjadi perubahan pula pada yang lainnya. Oleh sebab itu, dengan adanya perubahan sistem pembelajaran maka beberapa aspek dalam pembelajaran turut terdampak, di antaranya pada situasi pembelajaran, yakni kegiatan pembelajaran bukan lagi dilaksanakan dengan tatap muka langsung, melainkan tanpa tatap muka secara langsung. Hal ini membuat pembelajaran memiliki ruang gerak yang terbatas bagi siswa maupun guru, karena interaksi dibatasi oleh jarak. Dengan adanya jarak tersebut, cara atau metode pembelajaran pun turut berubah. Pembelajaran jarak jauh atau daring dilaksanakan berlawanan dengan pembelajaran konvensional, yakni siswa dan guru tidak langsung bertatap muka melainkan dibantu dengan media teknologi yang mempertemukannya, sehingga pemilihan metode pembelajaran dalam pembelajaran tersebut merupakan sesuatu hal yang pokok demi tersampaikannya materi kepada siswa [4].

Dari sekian banyak teknologi yang tersedia, internet merupakan satu-satunya media yang dianggap paling tepat untuk digunakan dalam proses pembelajaran jarak jauh, karena dapat menyatukan orang-orang dari berbagai daerah ke dalam suatu jaringan. Walaupun penggunaan internet sudah mengglobal, tetapi ketika digunakan dalam pembelajaran akan menjadi suatu hambatan, terlebih bagi siswa, karena penggunaan internet untuk pembelajaran jarak jauh belum dipersiapkan secara matang. Berbagai situasi tersebut akhirnya berdampak pada siswa, dan menjadikan siswa harus mempunyai handphone, kuota dan sinyal yang memadai, di samping siswa tetap harus menerima pelajaran.

Dalam sebuah literatur, kendala yang umumnya terjadi pada siswa dalam pembelajaran jarak jauh di antaranya yaitu sulitnya sinyal, terbatasnya kuota, meningkatnya tugas, dan berkurangnya penjelasan yang disampaikan guru [5]. Selain itu, akses internet yang terbatas, kaku dalam teknologi, aksi dalam pembelajaran berkurang, dan pelaksanaan evaluasi yang kurang terarah [6] pun turut menjadi dampak bagi para siswa.

Penjelasan-penjelasan di atas sejalan dengan penelitian terdahulu yang menyatakan bahwa pembelajaran jarak jauh di masa pandemi Covid-19 menimbulkan berbagai problematika dalam tanggapan dan juga perubahan pada sistem pembelajaran yang berpengaruh pada proses pembelajaran dan tingkat perkembangan siswa dalam merespon materi [7]. Berbagai dampak yang membuat berbagai perubahan akan mempengaruhi bagaimana respon siswa dalam melaksanakan pembelajaran jarak jauh. Adapun kegiatan siswa dalam mencapai tujuan-tujuan pembelajaran merupakan jantung dari proses pembelajaran, sehingga salah satu yang menjadi komponen inti dalam pembelajaran ialah siswa [8]. Maka respon siswa sebagai bentuk kepuasan dalam pembelajaran sangatlah penting, karena akan menentukan bagaimana sikap siswa 
dalam suatu pembelajaran [9]. Sebuah penelitian yang telah dilaksanakan menyatakan bahwa pada metode, media dan materi tertentu dalam pembelajaran jarak jauh yang dilaksanakan di sebuah sekolah, tingkat kepuasan siswa telah memperoleh kategori puas [11]. Siswa yang bersikap positif karena kepuasannya terhadap pembelajaran cenderung akan melaksanakan pembelajaran dengan sebaik mungkin, sehingga akan lebih mudah dalam mencapai tujuan pembelajaran. Maka kepuasan siswa juga dianggap penting karena akan menentukan berhasil tidaknya sebuah pembelajaran [10]. Oleh sebab itu, penulis merasa bahwa problematika dan kepuasan siswa perlu diperhatikan secara serius agar tercapainya tujuan-tujuan yang sudah ditetapkan, termasuk dalam situasi pandemi seperti saat ini.

Berdasarkan pemaparan dan penelitian relevan di atas yang fokus penelitiannya hanya pada aspek tertentu saja seperti problematika apa saja yang terjadi dalam kegiatan pembelajaran jarak jauh, serta kepuasan siswa dalam pembelajaran jarak jauh pada metode, media dan materi tertentu saja, maka penelitian ini mengkaji bagaimana tingkat problematika dan kepuasan siswa dalam pembelajaran jarak jauh pada berbagai dimensi pembelajaran yang lebih luas.

Penelitian dilakukan di SMP Negeri 1 Pamijahan yang sebelumnya belum pernah dilakukan penelitian terkait hal ini di lokasi tersebut. Selain itu, lokasi tersebut dipilih karena letaknya di sebuah pedesaan dan sudah mulai memasuki kawasan pengunungan. Sebagaimana yang diketahui bahwa dalam kawasan pegunungan akan sulit mendapatkan sinyal yang bagus. Di sisi lain, sinyal merupakan salah satu kebutuhan siswa dalam melaksanakan pembelajaran jarak jauh. Sehingga tujuan penelitian ini ialah untuk mengetahui problematika dan kepuasan siswa dalam menghadapi pembelajaran jarak jauh di sekolah menengah, yaitu di SMP Negeri 1 Pamijahan. Adapun penelitian ini dapat bermanfaat sebagai bahan referensi dalam melakukan pembenahan dalam pembelajaran jarak jauh, demi tetap tercapainya tujuan pembelajaran walau di masa pandemi Covid-19.

\section{METODE}

Penelitian ini merupakan jenis penelitian yang menggunakan metode kualitatif dengan pendekatan field research. Penelitian ini berfokus pada problematika dan kepuasan yang dihadapi siswa SMP Negeri 1 Pamijahan, Kabupaten Bogor. Teknik yang digunakan untuk mengumpulkan data yaitu observasi, angket dan dokumentasi. Angket yang menggunakan skala Guttman diberikan kepada siswa melalui google form dengan target $30 \%$ atau 270 dari jumlah seluruh siswa sebanyak 889 dengan teknik sampling incidental, yaitu siapa saja siswa yang pada saat itu memenuhi kriteria dalam artian memiliki kuota dan sinyal pada saat penyebaran link angket google form.

Untuk menjaga validitas dan reliabilitas dari angket yang diberikan, maka dilakukan uji validitas dan reliabilitas terhadap hasil angket. Data yang diperoleh merupakan data kuantitatif, kemudian dianalisis dan diterjemahkan ke dalam data kualitatif denga kriteria menurut Arikunto, yaitu $76 \%-100 \%=$ baik/puas, $56 \%-75 \%=$ cukup baik/cukup puas, $40 \%-55 \%=$ kurang baik/kurang puas, $0 \%-39 \%=$ tidak baik/tidak puas [12]. Analisis data berupa kegiatan reduksi data, penyajian data, dan kesimpulan atau verifikasi.

\section{HASIL DAN PEMBAHASAN \\ Problematika Siswa \\ Pembelajaran Jarak Jauh}

dalam 
Tabel 1. Problematika dalam Pembelajaran Jarak Jauh

\begin{tabular}{|c|c|c|c|c|c|}
\hline \multirow{2}{*}{ No } & \multirow{2}{*}{ Aspek } & \multicolumn{2}{|c|}{ Ya } & \multicolumn{2}{|c|}{ Tidak } \\
\hline & & $\Sigma$ & $\%$ & $\Sigma$ & $\%$ \\
\hline 1 & Penunjang & 171 & 63 & 99 & 37 \\
\hline 2 & $\begin{array}{l}\text { Proses } \\
\text { KBM }\end{array}$ & 119 & 44 & 151 & 56 \\
\hline 3 & Evaluasi & 177 & 66 & 93 & 34 \\
\hline \multicolumn{2}{|c|}{ Rata-Rata } & 156 & 58 & 114 & 42 \\
\hline
\end{tabular}

Problematika yang terjadi dalam pembelajaran jarak jauh, penulis membaginya ke dalam tiga aspek, yakni penunjang, proses Kegiatan Belajar Mengajar, dan kegiatan evaluasi dalam pembelajaran jarak jauh. Berdasarkan Tabel 1 dapat disimpulkan bahwa tingkat problematika pembelajaran jarak jauh yang terjadi di SMP Negeri 1 Pamijahan memperoleh persentase sebesar 58\%, sehingga berdasarkan kriteria interpretasi persentase menurut [12] termasuk dalam kategori cukup baik, karena berada di kisaran $56 \%-75 \%$ yang berarti problem yang terjadi tidak begitu serius.

Tabel 2. Penunjang Pembelajaran Jarak Jauh

\begin{tabular}{cccccc}
\hline \multirow{2}{*}{ No } & \multirow{2}{*}{ Aspek } & \multicolumn{2}{c}{ Ya } & \multicolumn{2}{c}{ Tidak } \\
\cline { 2 - 6 } & $\boldsymbol{\Sigma}$ & $\mathbf{\%}$ & $\boldsymbol{\Sigma}$ & $\mathbf{\%}$ \\
\hline 1 & $\begin{array}{l}\text { Pengetahuan } \\
\text { tentang } \\
\text { teknologi }\end{array}$ & 196 & 73 & 74 & 27 \\
2 & $\begin{array}{l}\text { Akses } \\
\text { internet } \\
\text { Kuota }\end{array}$ & 174 & 64 & 96 & 36 \\
& internet & 143 & 53 & 127 & 47 \\
\hline Rata-Rata & $\mathbf{1 7 1}$ & $\mathbf{6 3}$ & $\mathbf{9 9}$ & $\mathbf{3 7}$ \\
\hline
\end{tabular}

Pada aspek penunjang pembelajaran jarak jauh, terdapat tiga aspek di dalamnya yang membangun, yaitu:

1. Pengetahuan siswa mengenai penggunaan teknologi yang digunakan dalam pembelajaran jarak jauh, seperti HP, Laptop, dan internet memperoleh persentase sebesar $73 \%$, bagi siswa yang menjawab "Ya", dan siswa yang masih belum paham yakni sebesar $27 \%$. Maka problem ini masuk dalam kategori cukup baik, karena berada di kisaran 56\%-75\%.

2. Persentase siswa yang dapat mengaksesnya dengan baik sebesar $64 \%$, dan yang sulit untuk mengaksesnya sebesar 36\%. Maka problem ini termasuk dalam kategori cukup baik, karena berada di kisaran $56 \%-75 \%$.

3. Dalam aspek kuota internet, siswa yang dapat memilikinya dengan baik sebesar 53\% dan siswa yang tidak atau sulit memiliki kuota internet sebesar 47\%. Maka problem ini termasuk dalam kategori kurang baik, karena berada di kisaran 40\%-55\%.

Dengan demikian, berdasarkan Tabel 2, problem pada aspek penunjang pembelajaran jarak jauh di SMP Negeri 1 Pamijahan memperoleh persentase sebesar $63 \%$, sehingga masuk dalam kategori cukup baik, karena berada di kisaran 56\%$75 \%$ yang berarti bukan hal yang begitu serius.

Tabel 3. Proses Kegiatan Belajar Mengajar (KBM)

\begin{tabular}{clcccc}
\hline \multirow{2}{*}{ No } & \multirow{2}{*}{ Aspek } & \multicolumn{2}{c}{ Ya } & \multicolumn{2}{c}{ Tidak } \\
\cline { 3 - 6 } & \multicolumn{2}{c}{$\boldsymbol{\Sigma}$} & $\boldsymbol{\%}$ & $\boldsymbol{\Sigma}$ & $\mathbf{\%}$ \\
\hline 1 & Pemahaman \\
& $\begin{array}{l}\text { materi } \\
2\end{array}$ & 87 & 32 & 183 & 68 \\
3 & $\begin{array}{l}\text { Interaksi } \\
\text { Pembelajaran } \\
\text { cenderung }\end{array}$ & 106 & 39 & 164 & 61 \\
& 163 & 60 & 107 & 40 \\
& tugas & & & & \\
\hline & Rata-Rata & $\mathbf{1 1 9}$ & $\mathbf{4 4}$ & $\mathbf{1 5 1}$ & $\mathbf{5 6}$ \\
\hline
\end{tabular}

Pada aspek proses Kegiatan Belajar Mengajar (KBM) dalam pembelajaran jarak jauh, terdapat tiga aspek yang membangun di dalamnya, yaitu:

1. Pemahaman siswa terhadap materi yang disampaikan atau diberikan oleh guru memperoleh persentase sebesar $32 \%$ yang menjawab "Ya", dan siswa yang tidak dapat memahaminya dengan baik sebesar 68\%. Maka problem ini masuk dalam kategori 
tidak baik, karena berada di kisaran 0\%-39\%.

2. Siswa yang menyatakan dapat berinteraksi dengan baik bersama guru selama kegiatan pembelajaran sebesar $39 \%$, dan siswa yang tidak dapat berinteraksi dengan baik sebesar $61 \%$. Maka problem ini masuk dalam kategori tidak baik, karena berada di kisaran 0\%-39\%.

3. Pada aspek pembelajaran cenderung tugas, siswa yang menyatakan "Ya" merupakan mereka yang selalu mendapat uraian materi sebelum diberi penugasan, dengan persentase sebesar $60 \%$. Adapun yang menyatakan "Tidak" merupakan siswa yang tidak atau jarang mendapatkan uraian materi sebelumnya, sehingga kegiatan pembelajaran yang terjadi hanyalah pemberian tugas, yaitu sebesar $40 \%$. Maka problem ini masuk dalam kategori cukup baik, karena berada di kisaran 56\%-75\%.

Dengan demikian, berdasarkan Tabel 3, problem pada aspek Kegiatan Belajar Mengajar (KBM) dalam pembelajaran jarak jauh di SMP Negeri 1 Pamijahan memperoleh persentase sebesar $44 \%$, sehingga masuk dalam kategori kurang baik, karena berada di kisaran 40\%-55\% yang berarti problem yang terjadi cukup serius.

\section{Tabel 4. Evaluasi dalam Pembelajaran} Jarak Jauh

\begin{tabular}{cccccc}
\hline \multirow{2}{*}{ No } & \multirow{2}{*}{ Aspek } & \multicolumn{2}{c}{ Ya } & \multicolumn{2}{c}{ Tidak } \\
\cline { 3 - 6 } & $\boldsymbol{\Sigma}$ & $\mathbf{\%}$ & $\boldsymbol{\Sigma}$ & $\mathbf{\%}$ \\
\hline 1 & $\begin{array}{l}\text { Pemberian } \\
\text { tugas }\end{array}$ & 144 & 53 & 126 & 47 \\
2 & $\begin{array}{l}\text { Materi } \\
\text { yang } \\
\text { diujikan }\end{array}$ & 210 & 78 & 60 & 22 \\
\hline Rata-Rata & $\mathbf{1 7 7}$ & $\mathbf{6 6}$ & $\mathbf{9 3}$ & $\mathbf{3 4}$ \\
\hline
\end{tabular}

Pada aspek evaluasi dalam pembelajaran jarak jauh, terdapat dua aspek di dalamnya yang membangun, yaitu:
1. Pemberian tugas, yaitu gambaran kuantitas pemberian tugas yang diberikan guru kepada siswa selama pembelajaran jarak jauh. Siswa yang menyatakan "Ya" merupakan siswa yang tidak menerima tugas yang menumpuk selama masa pembelajaran jarak jauh, dengan persentase sebesar 53\%. Sedangkan siswa yang menyatakan "Tidak" merupakan siswa yang mendapatakan tugas yang menumpuk selama masa pembelajaran jarak jauh, dengan persentase sebesar 47\%. Maka problem ini masuk dalam kategori kurang baik, karena berada di kisaran 40\%-55\%.

2. Aspek materi yang diujikan, yaitu materi atau soal-soal dalam ulangan harian, Penilaian Tengah Semester (PTS) maupun Penilaian Akhir Semester (PAS) yang sebelumnya sudah dipelajari atau dibahas. Siswa yang menjawab "Ya" merupakan siswa yang menyatakan bahwa materi dalam kegiatan evaluasi rata-rata sudah dipelajari dengan persentase sebesar 78\%. Adapun yang menyatakan "Tidak" sebagai ungkapan dari banyaknya materi yang belum dipelajari sebelumnya sebesar $22 \%$. Maka problem ini masuk dalam kategori baik, karena berada di kisaran $76 \%-100 \%$.

Dengan demikian, berdasarkan Tabel 4, problem pada aspek evaluasi dalam pembelajaran jarak jauh di SMP Negeri 1 Pamijahan memperoleh persentase sebesar $66 \%$, sehingga masuk dalam kategori cukup baik, yang berarti problem yang terjadi bukan hal yang begitu serius.

\section{Kepuasan Siswa dalam Pembelajaran Jarak Jauh}

Kepuasan siswa dalam pembelajaran jarak jauh merupakan respon yang diberikan terhadap sebuah pembelajaran yang dilakukannya. Berikut tingkat kepuasan siswa SMP Negeri 1 Pamijahan dalam 
menghadapi pembelajaran jarak jauh. Siswa yang menyatakan "Ya" merupakan ungkapan siswa yang menyatakan kepuasannya, dan siswa yang menyatakan "Tidak" merupakan ungkapan yang menyatakan ketidakpuasannya.

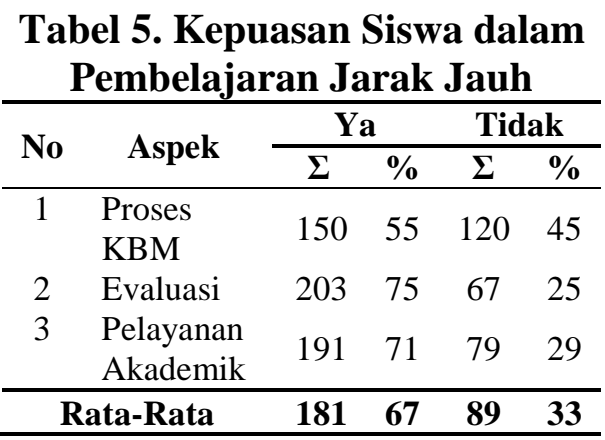

Kepuasan siswa dalam pembelajaran jarak jauh, dari lima indikator yang diturunkan ke dalam sebelas butir item, penulis merangkumnya kembali ke dalam tiga aspek, yakni proses Kegiatan Belajar Mengajar (KBM), evaluasi, dan pelayanan akademik. Berdasarkan Tabel 5, dapat disimpulkan bahwa tingkat kepuasan siswa dalam pembelajaran jarak jauh di SMP Negeri 1 Pamijahan memperoleh persentase sebesar 67\%, sehingga berdasarkan kriteria interpretasi persentase menurut [12] termasuk dalam kategori cukup puas, karena berada di kisaran $56 \%$ $75 \%$.

Tabel 6. Proses Kegiatan Belajar Mengajar

\begin{tabular}{clcccc}
\hline \multirow{2}{*}{ No } & \multicolumn{1}{c}{ Aspek } & \multicolumn{2}{c}{ Ya } & \multicolumn{3}{c}{ Tidak } \\
\cline { 3 - 6 } & & $\mathbf{\Sigma}$ & $\mathbf{\%}$ & $\mathbf{\Sigma}$ & $\mathbf{\%}$ \\
\hline 1 & Penggunaan teknologi & 162 & 60 & 108 & 40 \\
2 & $\begin{array}{l}\text { Penggunaan aplikasi } \\
\text { online }\end{array}$ & 161 & 60 & 108 & 40 \\
3 & Materi online & 111 & 41 & 159 & 59 \\
4 & Alokasi waktu KBM & 184 & 68 & 86 & 32 \\
5 & Metode pembelajaran & 128 & 47 & 142 & 53 \\
6 & $\begin{array}{l}\text { Respons guru dalam } \\
\text { materi yang tidak }\end{array}$ & 150 & 56 & 120 & 44 \\
& dipahami siswa & & & & \\
\hline$\quad$ Rata-Rata & $\mathbf{1 5 0}$ & $\mathbf{5 5}$ & $\mathbf{1 2 0}$ & $\mathbf{4 5}$ \\
\hline
\end{tabular}

Pada aspek proses Kegiatan Belajar Mengajar (KBM), terdapat enam aspek di dalamnya yang membangun, yaitu:

1. Penggunaan teknologi dalam pembelajaran jarak jauh, diperoleh persentase sebesar $60 \%$ bagi siswa yang menjawab "Ya", dan $40 \%$ siswa menjawab "Tidak". Maka aspek ini masuk dalam kategori cukup puas.

2. Dalam penggunaan aplikasi online diperoleh persentase sebesar $60 \%$ siswa yang menjawab "Ya", dan $40 \%$ siswa menjawab "Tidak". Sehingga tingkat kepuasan dalam aspek ini masuk dalam kategori cukup puas. Adapun berdasarkan hasil observasi, aplikasi online yang digunakan untuk pembelajaran jarak jauh di SMP Negeri 1 Pamijahan ialah hanya aplikasi WhatsApp (WA), Google Classroom, dan YouTube.

3. Materi yang diterima siswa melalui online atau daring memperoleh persentase sebesar $41 \%$ siswa yang menjawab "Ya", dan 59\% siswa menjawab "Tidak". Maka aspek ini masuk dalam kategori kurang puas.

4. Alokasi waktu Kegiatan Belajar Mengajar (KBM) memperoleh persentase sebesar 68\% siswa yang menjawab "Ya", dan $32 \%$ siswa menjawab "Tidak". Maka aspek ini masuk dalam kategori cukup puas.

5. Metode atau cara guru menyampaikan materi dalam pembelajaran jarak jauh memperoleh persentase sebesar $47 \%$ siswa yang menjawab "Ya", dan 53\% 
siswa menjawab "Tidak". Maka aspek ini masuk dalam kategori kurang puas.

6. Respon yang diberikan guru dalam menanggapi materi yang tidak dipahami oleh siswa memperoleh persentase sebesar 56\% siswa yang menjawab "Ya", dan 44\% siswa menjawab "Tidak". Maka aspek ini masuk dalam kategori cukup puas.

Dengan demikian, berdasarkan Tabel 6, tingkat kepuasan siswa dalalm aspek proses Kegiatan Belajar Mengajar (KBM) dalam pembelajaran jarak jauh di SMP Negeri 1 Pamijahan masuk dalam kategori kurang puas.

\section{Tabel 7. Evaluasi dalam Pembelajaran} Jarak Jauh

\begin{tabular}{cccccc}
\hline \multirow{2}{*}{ No } & \multirow{2}{*}{ Aspek } & \multicolumn{2}{c}{ Ya } & \multicolumn{2}{c}{ Tidak } \\
\cline { 2 - 6 } & $\mathbf{\Sigma}$ & $\mathbf{\%}$ & $\boldsymbol{\Sigma}$ & $\mathbf{\%}$ \\
\hline 1 & $\begin{array}{l}\text { Durasi } \\
\text { tugas }\end{array}$ & 201 & 74 & 69 & 26 \\
2 & $\begin{array}{l}\text { Pelaksanaan } \\
\text { ujian }\end{array}$ & 204 & 76 & 66 & 24 \\
\hline Rata-Rata & $\mathbf{2 0 3}$ & $\mathbf{7 5}$ & $\mathbf{6 7}$ & $\mathbf{2 5}$ \\
\hline
\end{tabular}

Pada aspek evaluasi dalam pembelajaran jarak jauh, terdapat dua aspek di dalamnya yang membangun, yaitu:

1. Durasi tugas, yakni lamanya pengerjaan dan pengumpulan tugas, memperoleh persentase sebesar 74\% siswa yang menjawab "Ya", dan 26\% siswa menjawab "Tidak". Maka durasi tugas yang diberikan kepada siswa termasuk dalam ketegori cukup puas.

2. Pelaksanaan ujian (ulangan harian, PTS, PAS) memperoleh persentase sebesar $76 \%$ siswa yang menjawab "Ya", dan 24\% siswa menjawab "Tidak". Maka pelaksanaan ujian termasuk dalam kategori puas.

Dengan demikian, berdasarkan Tabel 7, tingkat kepuasan siswa dalalm aspek evaluasi dalam pembelajaran jarak jauh di SMP Negeri 1 Pamijahan masuk dalam kategori cukup puas.
Tabel 8. Pelayanan Akademik dalam Pembelajaran Jarak Jauh

\begin{tabular}{cccccc}
\hline \multirow{2}{*}{ No } & \multirow{2}{*}{ Aspek } & \multicolumn{2}{c}{ Ya } & \multicolumn{2}{c}{ Tidak } \\
\cline { 2 - 6 } 1 & Bimbingan & $\mathbf{\Sigma}$ & $\boldsymbol{\Sigma}$ & $\mathbf{\%}$ \\
\hline $\begin{array}{l}\text { mengatasi } \\
\text { kejenuan } \\
2\end{array}$ & 172 & 64 & 98 & 36 \\
$\begin{array}{l}\text { Respons } \\
\text { terhadap } \\
\text { keluhan } \\
\text { siswa }\end{array}$ & 182 & 67 & 88 & 33 \\
3 & $\begin{array}{l}\text { Kesediaan } \\
\text { memberikan } \\
\text { solusi }\end{array}$ & 218 & 81 & 52 & 19 \\
\hline Rata-Rata & $\mathbf{1 9 1}$ & $\mathbf{7 1}$ & $\mathbf{7 9}$ & $\mathbf{2 9}$ \\
\hline
\end{tabular}

Pada aspek pelayanan akademik dalam pembelajaran jarak jauh terdapat tiga aspek di dalamnya yang membangun, yaitu:

1. Bimbingan dalam mengatasi kejenuhan, memperoleh persentase sebesar 64\% siswa yang menjawab "Ya", dan 36\% siswa menjawab "Tidak". Maka aspek ini masuk dalam kategori cukup puas.

2. Respons yang diberikan pihak sekolah terhadap keluhan siswa memperoleh persentase sebesar $67 \%$ siswa yang menjawab "Ya", dan 33\% siswa menjawab "Tidak". Maka aspek ini masuk dalam kategori cukup puas.

3. Kesediaan pihak sekolah dalam memberikan solusi kepada siswa memperoleh persentase $81 \%$ siswa yang menjawab "Ya", dan 19\% siswa menjawab "Tidak". Maka aspek ini masuk dalam kategori puas.

Dengan demikian, berdasarkan Tabel 8, tingkat kepuasan siswa dalalm aspek pelayanan akademik dalam pembelajaran jarak jauh di SMP Negeri 1 Pamijahan masuk dalam kategori cukup puas.

\section{SIMPULAN}

Dari hasil penelitian yang diperoleh dapat disimpulkan bahwa problematika pembelajaran jarak jauh di SMP Negeri 1 Pamijahan tergolong cukup baik, dengan arti tidak terjadi problem yang begitu serius. Namun terdapat beberapa aspek 
yang masuk dalam kategori tidak baik dan sangat perlu adanya perbaikan, yakni terjadi pada proses Kegiatan Belajar Mengajar (KBM) aspek pemahaman siswa terhadap materi online dan interaksi siswa dengan guru dalam pembelajaran. Adapun kepuasan siswa dalam pembelajaram jarak jauh di SMP Negeri 1 Pamijahan tergolong cukup puas. Beberapa aspek yang masuk dalam kategori kurang puas, dan sejalan dengan perolehan hasil dalam problematika pembelajaran jarak jauh, yakni pada proses Kegiatan Belajar Mengajar (KBM) aspek materi online dan metode pembelajaran.

\section{DAFTAR PUSTAKA}

[1] D. S. Nahdi dan M. G. Jatisunda. "Analisis Literasi Digital Calon Guru SD dalam Pembelajaran Berbasis Virtual Classroom di Masa Pandemi Covid-19". J. Cakrawala Pendas, vol. 6, no. 2, pp. 116-123, 2020.

[2] A. A. Muslim, V. M. Rafica, dan M. Zainuddin. "Pelatihan Manajemen Stres kepada Orang Tua Saat Pendampingan Pembelajaran Jarak Jauh Anak Stress Management Training for Parents During Child Distance Learning Assistance Abstract”. J. KANGMAS Karya Ilm. Pengabdi. Masy., vol. 1, no. 3, pp. 140-152, 2020.

[3] S. Y. Simanjuntak dan Kismartini. "Respon Pendidikan Dasar terhadap Kebijakan Pembelajaran Jarak Jauh Selama Pandemi Covid-19 di Jawa Tengah". J. Ilm. Wahana Pendidik., vol. 6, no. 3, pp. 308-316, 2020.

[4] U. H. Salsabila, L. I. Sari, K. H. Lathif, A. P. Lestari, dan A. Ayuning. "Peran Teknologi dalam Pembelajaran di Masa Pandemi Covid-19”. Al-Mutharahah J. Penelit. dan Kaji. Sos. Keagamaan, vol. 17, no. 2, pp. 188-198, 2020.
[5] A. Rohmanu, E. Muafiah, A. R. Hakim, dan V. V. W. Damayanti. "Kesiapan, Kompleksitas dan Harapan Pembelajaran Jarak Jauh: Perspektif Mahasiswa IAIN Ponorogo". At-Tadzkiyyah J. Pendidik. Islam, vol. 11, no. 2, pp. 221-241, 2020.

[6] M. Y. A. Nugroho. "Metode, Media, dan Problematika Pembelajaran Pai Berbasis Daring di Tingkat Madrasah Aliyah". J. Paramurobi, vol. 3, no. 2, pp. 1-14, 2020.

[7] A. M. Basar. "Problematika Pembelajaran Jarak Jauh pada Masa Pandemi Covid-19 (Studi Kasus di SMPIT Nurul Fajri - Cikarang Barat - Bekasi)". Edunesia J. Ilm. Pendidik., vol. 2, no. 1, pp. 208-218, 2021.

[8] M. D. R. Konsep Pembelajaran Aqidah Akhlak, Ke-1. Yogyakarta: Deepublish, 2016.

[9] D. Shabrina dan I. Z. Ratnaningsih. "Hubungan antara Work Life Balance dengan Kepuasan Kerja pada Karyawan PT. Pertani (Persero)". J. Empati, vol. 8, no. 1, pp. 27-33, 2019.

[10] F. A. Rondonuwu. "Pengaruh Worklife Balance terhadap Kepuasan Kerja Karyawan pada Hotel Sintesa Peninsula Manado". J. Adm. Bisnis, vol. 7, no. 2, pp. 30-38, 2018.

[11] W. Nugroho. "Kepuasan Siswa terhadap Pembelajaran Daring Menggunakan Microsoft Teams dan Video Youtube pada Materi Program Linier". J. THEOREMS (The Orig. Res. Math., vol. 5, no. 2, pp. 111121, 2021.

[12] A. S. Ifadah. "Literasi : Pemahaman Konsep Buaya Literasi Baca - Tulis untuk Anak Usia Dini”. J. Golden Age, Univ. Hamzanwadi, vol. 04, no. 2, pp. 290-296, 2020. 